\title{
Prevalence and Molecular Characterization of Group a Rotavirus in Children of Punjab, India
}

\author{
Gurlal Singh Gill ${ }^{1 *}$, Simranpreet Kaur ${ }^{1}$, Padam Nath Dwivedi ${ }^{2}$ and \\ Jatinder Paul Singh Gill ${ }^{1}$
}

\author{
${ }^{1}$ School of Public Health and Zoonoses, Guru Angad Dev Veterinary and Animal Sciences \\ University, Ludhiana, Punjab, India \\ ${ }^{2}$ Department of Veterinary Microbiology, Guru Angad Dev Veterinary and Animal Sciences \\ University, Ludhiana, Punjab, India \\ *Corresponding author
}

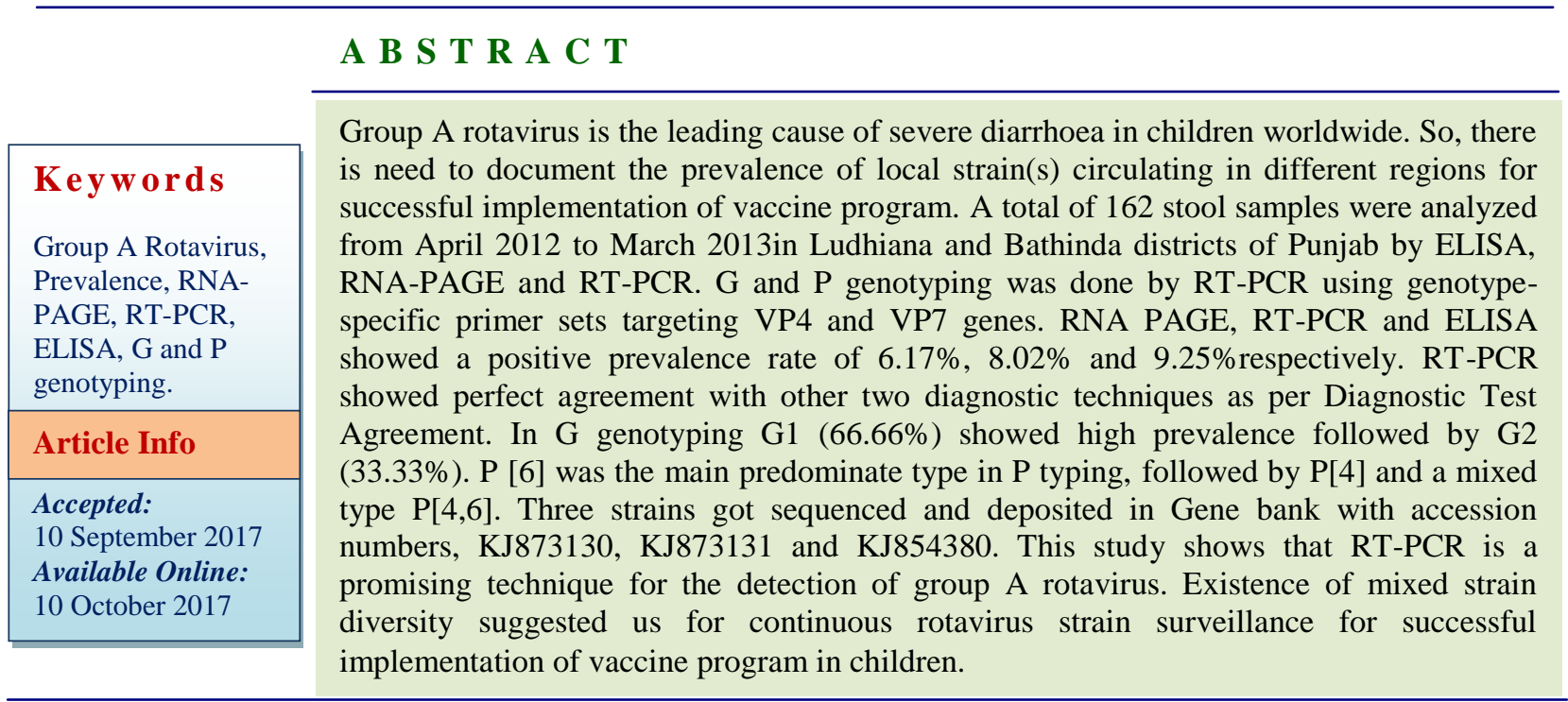

\section{Introduction}

Acute diarrhoeal disease or gastroenteritis continues to be a significant clinical problem throughout the world. As a major cause of hospitalization and child deaths globally, the diarrhoeal diseases account for approximately one in six deaths among children younger than five years. In India about 334000 annual deaths among children are attributable to diarrhoeal diseases (Parashar et al., 2004; Black et al., 2010; Million Death Study Collaborators, 2010). Group A Rotavirus infection is the most common cause of severe gastroenteritis in children $<5$ years of age worldwide and accounts for five per cent of all deaths among children in this age group (WHO, 2009).

Rotaviruses are members of the family Reoviridae. The genus rotavirus is classified into seven different serogroups (A-G), on the basis of the antigen specificity of the capsid proteins in the virus, as well as on the basis of the electrophoretic mobility of the 11 RNA segments of the viral genome. Of the seven 
rotavirus serogroups, only groups A-C are known to zoonotic importance (Broor et al., 2003). Among all groups group A rotavirus is the major cause of gastroenteritis in infants and young children, and in neonates of farm animals (Kapikian et al., 2001).

Rotaviruses (RVs) have two independent neutralization antigens on the outer capsid, VP7 and VP4, which establish G and P types, respectively. In extensive genomic studies, 14 $\mathrm{P}$ genotypes and $26 \mathrm{G}$ genotypes have been established for rotaviruses of humans and animals (Martella et al., 2006). The major human G types G1, G2, G3, G4, and G9, which, combined with the $\mathrm{P}$ types $\mathrm{P}[8], \mathrm{P}[4]$ and $\mathrm{P}[6]$ account for more than 80 per cent of rotavirus-associated gastroenteritis episodes worldwide (Gentsch et al., 2005).

As the virus is excreted in large numbers in the faeces, it can be diagnosed easily by electron microscopy which is one of the most specific tests. The other most widely used methods currently are latex agglutination, ELISA and polyacrylamide gel electrophoresis (PAGE) (Herring et al., 1982; Herrmann and Blacklow, 1995).

The detection by PAGE followed by silver staining is a highly specific technique, but lacks sensitivity as a minimum of 3-4 ng of viral RNA is needed for detection (Herring et al., 1981). Newer techniques like dot blot hybridization using radio labeled cDNA probes, reverse transcriptase- polymerase chain reaction (RT-PCR), Real-Time PCR, and automated nucleotide sequencing are now being used as confirmatory methods for detecting rotavirus in stool samples (Broor et al., 1995; Wilde et al., 1990; Husain et al., 1995). A multiplex, semi-nested RT-PCR method is currently being used for identifying $\mathrm{G}$ and $\mathrm{P}$ genotypes of rotavirus (Gouvea et al., 1990; Gentsch et al., 1992).
The age old traditions of livestock animals and human beings living in the same household and socio-economic conditions in India, leads to interspecies transmission of rotaviruses. This contributes to the generation of diversity of rotaviruses infecting humans (Vesikari et al., 1984). Objectives of the study were to estimate the prevalence of rotavirus infection and to identify the $G$ and $P$ genotypes prevailing in a Punjab region, with an overall goal of providing information to the health authorities for effectively implementation of rotavirus vaccine program in India.

\section{Materials and Methods}

\section{Sample collection and extraction of rotavirus dsRNA from faecal sample}

A total of 162 stool samples were collected from diarrhoeal (150) and non-diarrhoeal (12) cases of children between a day old to five year of age from various laboratories and private pediatric hospitals of Ludhiana and Bathinda districts of Punjab during the period from April 2012 to March 2013. The samples were collected in sterile stool collection vials, properly labelled and immediately transferred to the laboratory under chilled conditions and stored at $-20^{\circ} \mathrm{C}$. Trizol extraction method (TRIzol (R) reagent Ambion) as per the manufacturer's protocol, was used for extraction of dsRNA of rotavirus from faecal samples. The isolated RNA was then used for further downstream applications.

\section{Detection of Group A rotavirus from faecal samples}

Three methods viz., RNA-PAGE, ELISA and RT-PCR were standardized for the detection of group A rotavirus. All the positive samples by RT-PCR were further subjected to genotypic characterization for $\mathrm{G}$ and $\mathrm{P}$ typing by seminested PCR typing assay. 


\section{Detection of Group A rotavirus RNA by RNA-PAGE}

The RNA extracted from the faecal sample was subjected to ribonucleic acid-poly acrylamide gel electrophoresis (RNA-PAGE) as per the procedure described by Laemmli (1970) and Herring et al., (1982) with concentration of separating gel of $7.5 \%$ and stacking gel of $5 \%$ at $150 \mathrm{~V}$ on vertical slab gel electrophoresis apparatus.

The gel was silver stained as per the method described by Bassam et al., (1991) photographed and stored in 10\% ethanol.

\section{Detection of Group A rotavirus by ELISA}

All the faecal samples were screened for the presence of rotavirus antigen by using Ridascreen ${ }^{\circledR}$ Rotavirus Test, A commercial enzyme immunoassay kit, procured from RBiopharm AG, Germany as per the manufacturer's instructions. The optical densities were read at $450 \mathrm{~nm}$ in microplate reader (Nano quant Infinite M 200 PRO).

Detection of Group A rotavirus by reverse transcription-polymerase chain reaction (RT-PCR)

The RNA was transcribed into cDNA using reverse transcriptase enzyme with VP7 gene specific primers (Forward GAT CCG AAT GGT TGT GTA ATC CAA T Reverse AAT TCG CTA CGT TTT CTC TTG G) and amplified using same primers as described by Husain et al., (1995) in a thermalcycler (Eppendorf Germany). The resultant PCR products were analysed by agarosegel electrophoresis with $4 \mu \mathrm{g} / \mathrm{ml}$ concentration of Ethidium bromide. The PCR product size (304 bp) was determined by comparing with a standard molecular weight marker $(100 \mathrm{bp}$ DNA ladder) and digitally recorded by gel documentation system (G:BOX, SYNGENE).

\section{Characterization of rotavirus}

The positive isolates obtained by RT-PCR were subjected to $\mathrm{G}$ and $\mathrm{P}$ genotyping as per the details given below.

\section{G genotyping}

The cDNA was synthesized and amplified using RT-PCR with VP7 gene specific primers Beg9 End9 in a thermalcycler as described by Gouvea et al., (1990). Briefly, a $1062 \mathrm{bp}$ (full-length) gene segment nine, encoding the VP7 glycoprotein of Human group A rotaviruses was amplified.

This was followed by two semi-nested PCR by using $G$ type specific primers, as per described by Gouvea et al., (1990) and Gouvea et al., (1994a).

\section{P genotyping}

Through RT-PCR, cDNA was synthesized and amplified by using VP4 gene specific primers Con3Con 2 as described by Gentsch et al., (1992) in a thermalcycler, (Eppendorf, Germany). PCR product size of $876 \mathrm{bp}$ encoding VP4 gene of human group A rotavirus was amplified and followed with two semi-nested PCR by using P type specific primers as described by Gentsch et al., (1992) and Gouvea et al., (1994 b).

\section{Sequencing of selected genotypes of rotavirus}

Some of the selected amplified PCR products of VP7 and VP4 genes of Human rotaviruses were got sequenced. The nucleotide sequence data were deposited in GenBank (Accession no: KJ873130, KJ873131 and KJ854380) using the National Center for Biotechnology Information (NCBI, Bethesda, MD) Sequin 5.15 submission tool http:/ www3.ncbi.nlm.nih.gov. 


\section{Statistical analysis}

Comparative statistical analysis of the detection methods used for group A rotavirus, namely RNA-PAGE, RT-PCR, and ELISA was performed using Diagnostic test agreement employing a software Win Episcope 2.0 version. The comparative statistical analysis was performed to ascertain the best technique for detection of group A rotavirus. The kappa value was measured to find agreement between positive and negative results of these the three detection techniques at $95 \%$ confidence level. The confirmation was done on the basis of kappa value, with the kappa value less than zero indicating no agreement, $0-0.20$ as slight, $0.21-0.40$ as fair, $0.41-0.60$ as moderate, $0.61-0.80$ as substantial, and $0.81-1$ as almost perfect agreement.

\section{Results and Discussion}

\section{Detection and comparative prevalence of Group A rotavirus}

All 162 stool samples of children between a day old to five year of age were screened for group A rotavirus by RNA-PAGE, ELISA and RT-PCR, all the non-diarrhoeal samples were found negative for rotavirus by these three detection techniques. The overall prevalence of group A rotavirus in children as observed by electropherotypic analysis is found to be $6.17 \%$ i.e. out of 162 samples ten samples were positive (Fig. 1). Maximum samples (8) showed long electropherotype pattern, whereas two displayed short E-types. The results are in co-ordination to the findings of Das et al., (2002) who collected samples from Infectious Diseases Hospital, Kolkata and found $7.3 \%$ prevalence rate. Whereas Broor et al., (1993) detected (10.5\%) perevalence of rotavirus type A from 25month study period. Dash et al., (2012) and Kaur (2011) found $20.9 \%$ and $28.29 \%$ prevalence rate of group A rotavirus in north India respectively. Possibly the reason for high prevalence, may be due to the fact that they collected more samples, under one year of age and this age is more susceptible to disease.

Maximum samples eight out of ten (80\%), showed long electropherotype pattern and two (20\%) samples show short electropherotype in our study and it is supported by majority of the earlier studies, in which long pattern seems to be dominant (Esona et al., 2003; Urbina et al., 2004; Kaur, 2011).

Prevalence of group A rotavirus in children by RT-PCR is found to be $8.02 \%$ (13/162) (Fig. 2). The results are in line with another study conducted by Husain et al., (1995) who collected 450 faecal samples from children with acute diarrhoea from Delhi and detected 63 (14\%) samples positive with group A rotavirus by RT-PCR. In contrast to our study Kaur (2011) detected 36.59\% prevalence rate from Punjab. Reason of less prevalence rate in present study could be that maximum sampling is done during summer season and more samples are collected from 1.5- 5 year of age group, age and season play important role in prevalence so, we got less prevalence rate.

On screening of all stool samples by ELISA, $9.25 \%(15 / 162)$ prevalence rate of group a rotavirus antigen is detected. In India previous studies shows a lot of variation $(4.3 \%$ to $41.46 \%)$ in the prevalence of rotavirus by ELISA (Chakravarti et al., 1992; Yachha et al., 1993; Sarvanan et al., 2004; Kaur, 2011; Mathew et al., 2014).

The variation in these studies from the present study can be attributed to the age group, season of sample collection as well as the sensitivity and specificity of ELISA technique used. 
All three techniques PAGE, RT-PCR and ELISA were compared on the basis of their positive and negative results by a statistical method, namely Diagnostic test agreement.

The RT-PCR showed more correlated results with RNA-PAGE and ELISA. The analysis of data revealed that RT-PCR is more accurate than ELISA and RNA-PAGE for the detection of group A rotavirus. Other studies also indicate that PCR is the best confirmatory detection technique for group A rotavirus in faecal samples (Wilde et al., 1990; Husain et al., 1995; Slovis et al., 2014).

The detection by PAGE followed by silver staining is a highly specific technique, but lacks sensitivity as a minimum of 3-4 $\mathrm{ng}$ of viral RNA is needed for detection (Herring et al., 1981). Moreover ELISA is very sensitive technique but false positive results are very common in ELISA assays due to complex sample matrix, which can increase the probability of cross-reactions.
Season, age and gender-wise prevalence in children

The prevalence of rotavirus diarrhea among children shows a marked seasonal variation. Out of a total 56 samples screened during the winter period (November to February), nine are found positive for group A rotavirus, which accounted for $16.07 \%$ of the total cases. A prevalence of $5.8 \%$ is recorded in the months of July to October, corresponding to rainy season. A total of 37 samples are collected in hot and dry summer season between March and June and all are found negative. Thus, analysis of season in relation to rotavirus infection from Punjab revealed a significant association of the occurrence of infection with cooler months. The results of the present study are comparable with previous studies (Saravanan et al., 2004;Bahl et al., 2005; Kang et al., 2009; Kaur, 2011), who have reported the pre-dominance of human rotavirus infection during cooler months in India.

Fig.1 RNA-PAGE showing electrophoretic migration of human group A rotavirus genome. (A) Lane S - Positive Control; Lane N - Negative Control; Lane H1, H2, H3, H4 - Positive Diarrhoea Samples. (B) Shows 11 Segments of the Double Stranded RNA of Group A Rotavirus, Separated on RNA-PAGE

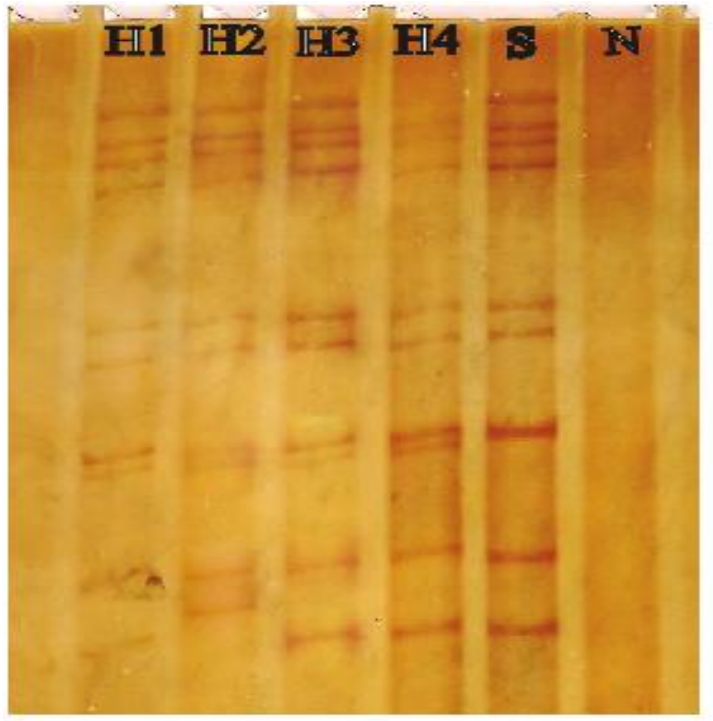

(A)

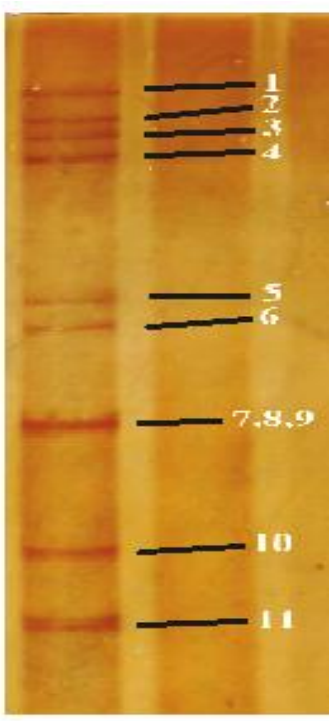

(B) 
Fig.2 RT-PCR amplification of conserved part of VP7 gene of human group A rotavirus with 304 bp amplicon. From Left to Right: Lane L - 1000 bp Plus DNA Ladder; Lane R - Positive Control; Lane R1, R2, R3, R4, R5 - Positive Diarrhoeal Samples; Lane N - Negative Control

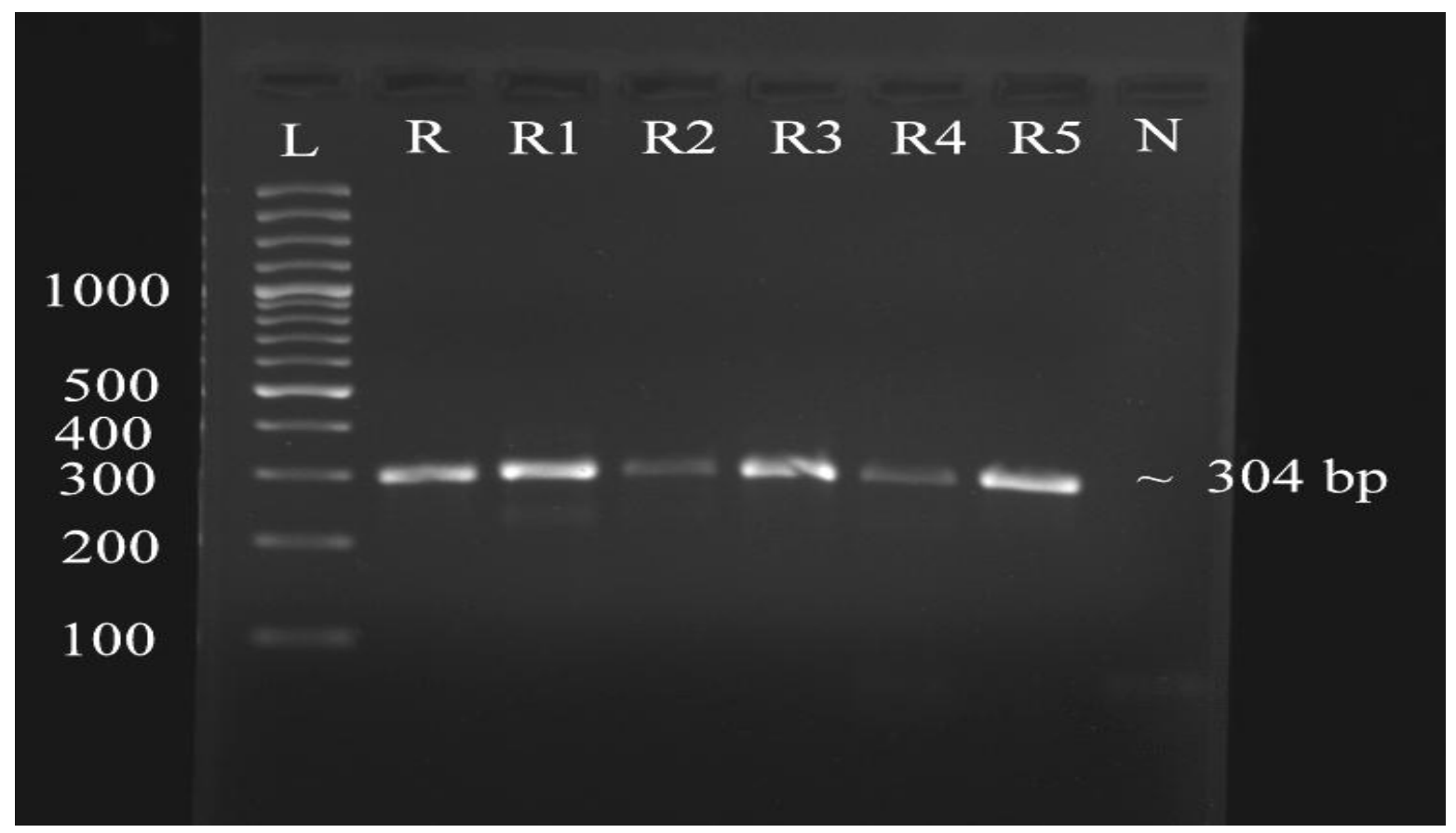

Fig.3 PCR amplification of VP7 gene of human group A rotavirus with 1062 bp Amplicon. From Left to Right: Lane L - 1000bp Plus DNA Ladder; Lane G1, G2, G3, G4 - Positive Diarrhoea Samples; Lane G - Positive Control; Lane N - Negative Control

\section{G G1 G2 G3 G4 X N}


Fig.4 PCR amplification of VP4 gene of human group A rotavirus with 876 bp amplicon. Left to Right: Lane L - 1000 bp plus DNA ladder; Lane P1, P2, P3, P4, P5 - Positive Diarrhoea Samples, Lane P - Positive control; Lane N - Negative control

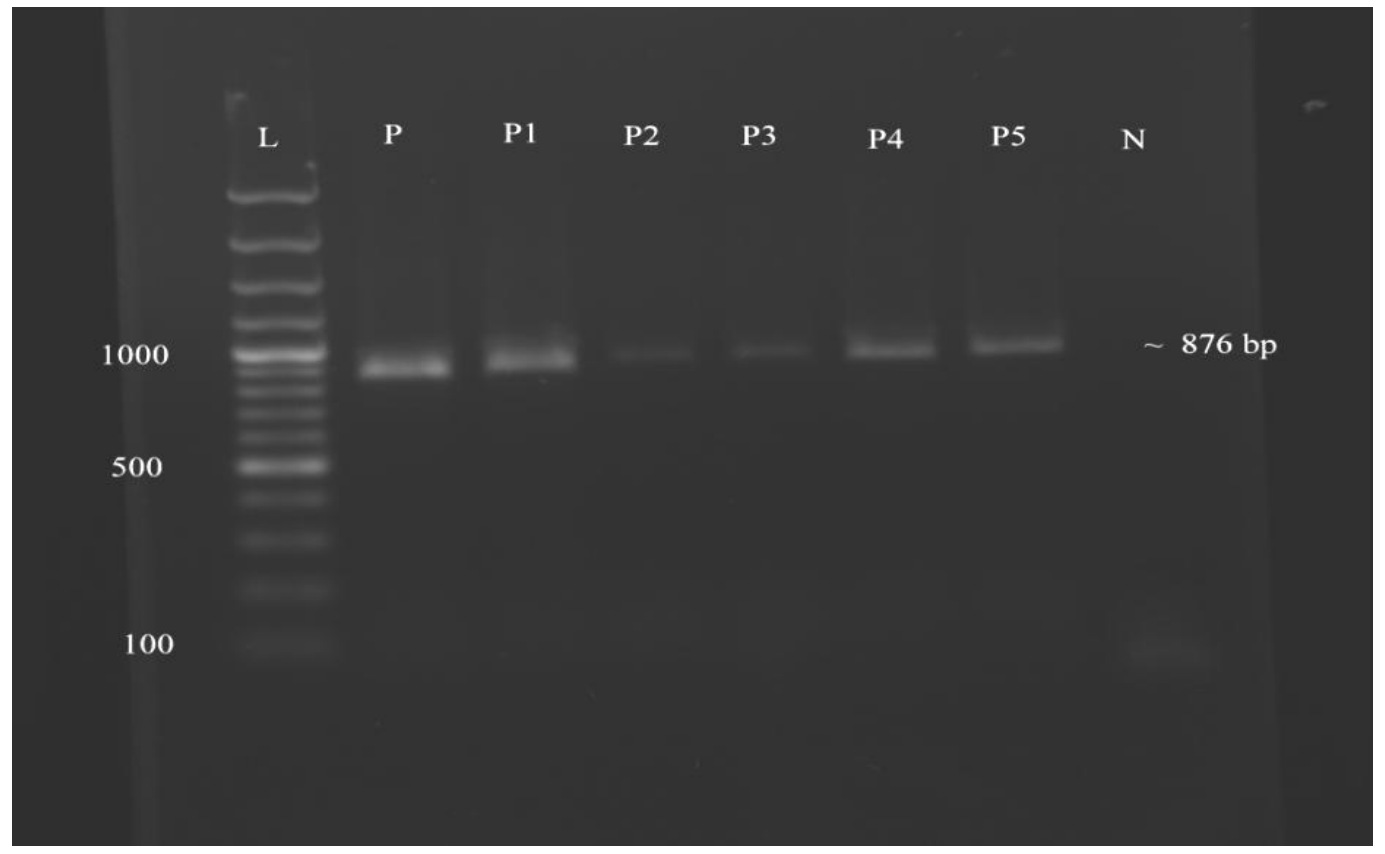

Fig.5 PCR based G genotyping showing G1 with 749 bp and G2 with 652 bp; Lane L - 1000 bp Plus DNA Ladder; Lane H1, H2 - Positive for G1 Type; Lane H3 - Positive for G2 type; Lane $\mathrm{N}$ - Negative Control

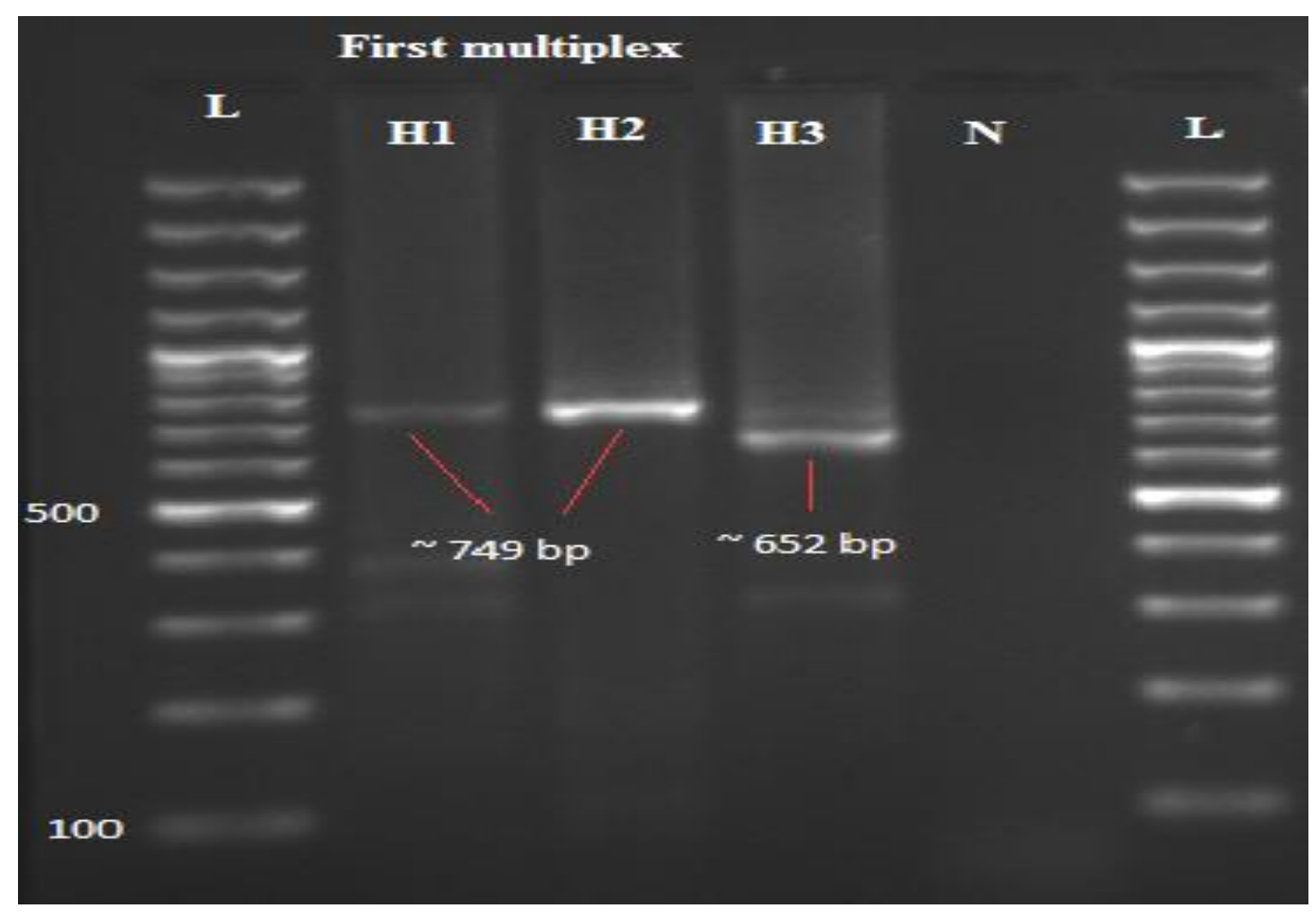


Fig.6 PCR Based P genotyping showing P[4] with 483 bp and P[6] with 423 bp. Lane L 1000bp Plus DNA Ladder; In 3rd Multiplex, Lane H3 - Positive for P[4] Type; Lane N -

Negative Control; In $4^{\text {th }}$ Multiplex, Lane H1, H2, H3- Positive for P[6] Type;

Lane N - Negative Control

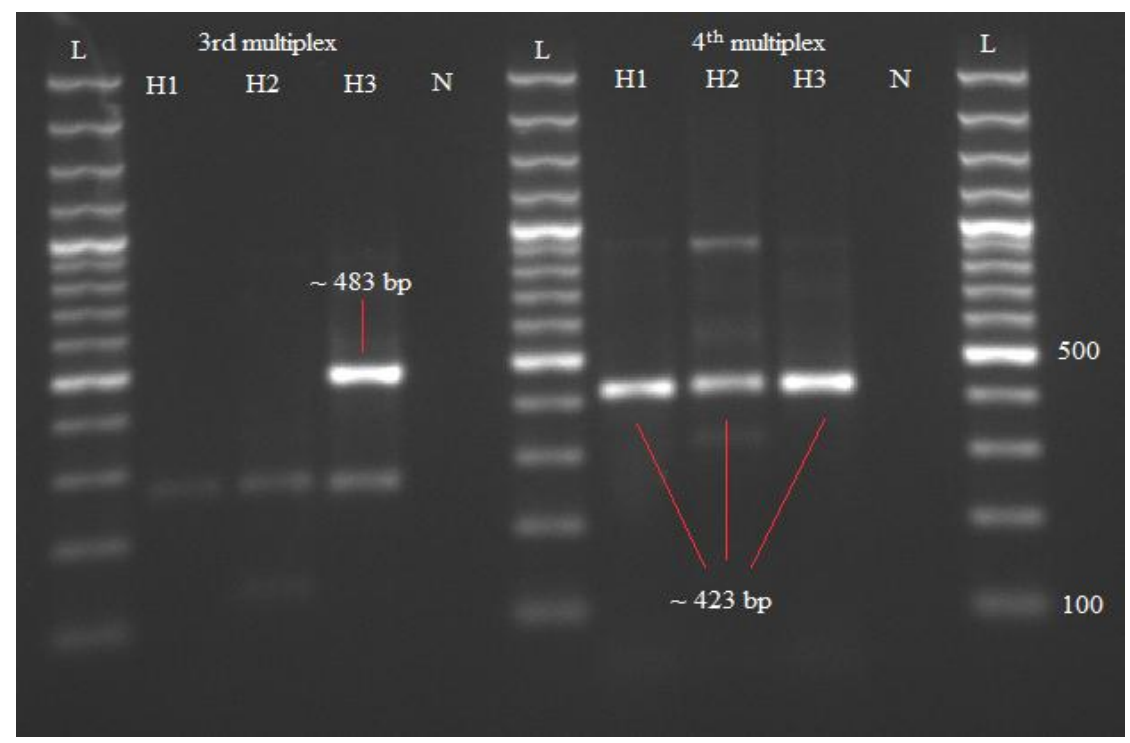

Table.1 Age-wise distribution of Group A rotavirus in children

\begin{tabular}{|c|c|c|c|c|}
\hline $\begin{array}{l}\text { S. } \\
\text { No. }\end{array}$ & Age Groups & $\begin{array}{c}\text { No. of } \\
\text { Samples } \\
\text { Screened }\end{array}$ & $\begin{array}{c}\text { No. of } \\
\text { Samples } \\
\text { Positive }\end{array}$ & $\begin{array}{c}\text { \% Positive for } \\
\text { Group A } \\
\text { Rotavirus }\end{array}$ \\
\hline 1 & Day old to 3months & 25 & 2 & 8 \\
\hline 2 & $3-6$ months & 17 & 3 & 17.64 \\
\hline 3 & $6-9$ months & 15 & 3 & 20 \\
\hline 4 & $9-12$ months & 16 & 2 & 12.5 \\
\hline 5 & $12-15$ months & 19 & 1 & 5.26 \\
\hline 6 & $15-18$ months & 22 & 1 & 4.54 \\
\hline 7 & $18-24$ months & 20 & 1 & 5 \\
\hline 8 & $2-5$ years & 28 & - & - \\
\hline
\end{tabular}

The correlation of rotavirus gastroenteritis with the age of the subject is studied by grouping the children of different age into eight groups, as depicted in (Table 1). The peak incidence of rotavirus gastroenteritis is found in six to nine months age group, in which $20 \%$ had rotavirus diarrhoeic episodes, followed by the 3-6 month age group with an incidence $17.64 \%$, day old to three month (8\%) positive samples. All samples are negative beyond two year. Thus children below 1 year of age are found to be more susceptible to rotavirus infection and it may be due to lack of fully developed immune system. The results of the present study are in agreement with other previous reports (Sarvanan et al., 2004; Bahl et al., 2005; Kang et al., 2009).

In the present study, out of a total of 162 samples, rotavirus is detected in $8.8 \%(8 / 91)$ males and $7.04 \%$ (5/71) females stool samples 
are detected positive for rotavirus. The possible reason for this might be that more number of samples are collected from male children, but some researchers also support our study (Saravanan et al., 2004; Banerjee et al., 2006; Junaid et al., 2011).

\section{Molecular characterization of group A rotavirus in children}

A total of nine $(69.23 \%)$ positive samples out of 13 are available in sufficient quantity for further analysis ( $\mathrm{G}$ and $\mathrm{P}$ typing). Six samples are successfully amplified with both VP7 (Fig. 3) and VP4 (Fig. 4) gene based primers, whereas rest of the samples $(n=3)$ are not amplified which could be due to either non specific inhibition of PCR by the components of faecal matrix that are carried through the extraction procedure or non - typeable with available primers (Xu et al., 1990; Ushijima et al., 1994; Steele et al., 1995).

The six samples which could be amplified by nested multiplex PCR, exhibited different combinations of $\mathrm{G}$ and $\mathrm{P}$ genotypes. G1P [6] is seen in three samples and rest of three samples are G1P [4], G2P [6] and G2P [4, 6]. Mixed genotype (G2P [4, 6]) is observed in one sample out of six samples. High incidence rate is showed by G1 $(66.66 \%)$ that is four out of six samples whereas incidence rate of $\mathrm{G} 2$ is $33.33 \%$ (Fig. 5). In $\mathrm{P}$ typing, $\mathrm{P}$ [6] showed more incidence four out of six samples, rest of two samples are $\mathrm{P}$ [4] and mixed type $\mathrm{P}[4,6]$ (Fig. 6). Hence $\mathrm{G} 1$ and $\mathrm{P}$ [6] are the predominant types in this study.

In coordination to our study Das et al., (2002) report $\mathrm{G}$ and $\mathrm{P}$ types from Eastren India: G1 (38\%), G2 (24\%), G4 (12.6\%), and mixed (7\%), only two $\mathrm{P}$ types were predominant in Kolkata P [8] (37\%) and P [4] (26\%). The other types observed are P [6] (6\%), mixed $\mathrm{P}$ types $(19 \%)$ and $13 \%$ untypeable strains. The mixed $\mathrm{P}$ types consisted of $\mathrm{P}[4] \mathrm{P}[8]$,
$\mathrm{P}[6] \mathrm{P}[8]$, and $\mathrm{P}[4] \mathrm{P}[6] \mathrm{P}[8]$ in this study. In another study G1, G2, and G9 are observed by Sharma et al., (2008) to be widely circulating genotypes in Delhi, with overall incidences of $25.8 \%, 24.9 \%$, and $14.4 \%$, Among the $\mathrm{P}$ types, $\mathrm{P}$ [4], $\mathrm{P}$ [6], and $\mathrm{P}$ [8] accounted for $19.3 \%, 22.4 \%$, and $34.8 \%$ of the total rotavirus-positive samples, respectively. Some earlier studies shows similar trends in India with G1 as the most predominant type followed by G2 (Ramani and Kang, 2007; Samajdar et al., 2008).

From the above study it can be concluded that RT PCR is the most promising technique for the detection of group A rotavirus. Group A rotavirus infection is more prevalent during winter months and children below one year age are high susceptible for rotavirus infection. Existence of mixed strain diversity suggested us for continuous rotavirus strain surveillance for successful implementation of vaccine program in India.

\section{Acknowledgement}

The authors are grateful to Director Research, GADVASU, Punjab, India for their support in research. The authors also express their appreciation to the children, parents and staff of hospitals and laboratories of Bathinda and Ludhiana districts of Punjab who participated in this study.

\section{References}

Bahl, R., P. Ray, S. Subodh, P. Shambharkar, M. Saxena, U. Parashar, J. Gentsch, R. Glass, M. K. Bhan and Delhi Rotavirus Study Group. 2005. Incidence of Severe Rotavirus Diarrhoea in New Delhi, India, and $G$ and $P$ Types of the Infecting Rotavirus Strains. J. Infect. Dis. 192: S114-119.

Banerjee, I., S. Ramani, B. Primrose, P. Moses, M. Iturriza-Gomara, J. Gray, S. 
Jaffar, B. Monica, J. P. Muliyil, D. W. Brown, M. K. Estes and Kang G. 2006. Comparative study of rotavirus epidemiology in children from a community based birth cohort and a tertiary hospital in south India. J. Clin. Microbiol. 44: 2468-2474.

Bassam, B.J., G.C. Anollés and Gresshoff P.M. 1991. Fast and sensitive silver staining of DNA in polyacrylamide gels. Anal. Biochem. 196: 80-83.

Black, R.E., S. Cousins, H.L. Johnson, J.E. Lawn, I. Rudan and Global, regional, and national causes of child mortality in 2008: A systematic analysis. Lancet 2010. 375: 1969-1987

Broor, S., D. Ghosh and Mathur P. 2003. Molecular epidemiology of rotaviruses in India. Indian. J. Med. Res. 118: 5967.

Broor, S., M. Husain, B. Chatterjee, A. Chakraborty and Seth P. 1993. Temporal variation in the distribution of rotavirus electropherotypes in Delhi, India. J. Diarrhoeal. Dis. Res. 11: 14-18.

Broor, S., M. Husain, B. Chatterjee, A.Chakraborty and Seth, P. 1995. Direct detection and characterization of rotavirus into subgroups by dot blot hybridization and correlation with 'long' and 'short' electropherotypes. Clin. Diagn.Virol. 3: 29-38.

Chakravarti, A., S. Kumar, S. K. Mittal and Broor S. 1992. Clinical and epidemiological features of acute gastroenteritis caused by human rotavirus subgroups. J. Diarrhoeal. Dis. Res. 10: 21-24.

Das, S., A. Sen, G. Uma, V. Varghese, S. Chaudhuri, S.K. Bhattacharya, T. Krishnan, P. Dutta, D. Dutta, M.K. Bhattacharya, U. Mitra, N. Kobayashi and Naik T. N. 2002. Genomic diversity of group A Rotavirus strains infecting humans in eastern India. J. Clin. Microbiol. 40: 146-149.
Dash, S. K., K. Kumar, and Bhatia A. K. 2012. Detection of Rotavirus from Hospitalized Diarrheic Children in Uttar Pradesh, India. Indian. J. Microbiol. 52(3): 472-477.

Esona, M. D., G.E. Armahand Steele A. D. 2003. Molecular epidemiology of rotavirus infection in Western Cameroon. J. Trop. Pediatr. 49: 160163.

Gentsch, J. R., A. R. Laird, B. Bielfelt, D. D. Griffin, K. Banyai, M. Ramachandran, V. Jain, N. A. Cunliffe, O. Nakagomi, C. D. Kirkwood, T. K. Fischer, U. D. Parashar, J. S. Bresee, B. Jiang and Glass R. I. 2005. Serotype diversity and reassortment between human and animal rotavirus strains: implications for rotavirus vaccine programs. J. Infect. Dis. 192: S146-S159.

Gentsch, J. R., R.I. Glass, P. Woods, V. Gouvea, M. Gorziglia, J. Flore, B. K. Das, and Bhan M. K. 1992. Identification of group A rotavirus gene 4 types by polymerase chain reaction. J.Clin. Microbiol. 30: 1365-1373.

Gouvea, V., N. Santos and Timenetsky C. M. 1994a. Identification of bovine and porcine rotavirus $\mathrm{G}$ types by PCR. J. Clin. Microbiol. 32: 1338-1340.

Gouvea, V., N. Santos and Timenetsky C. M. 1994b. VP4 typing of bovine and porcine group A rotaviruses by PCR. J. Clin. Microbiol. 32: 1333-1337.

Gouvea, V., R. I. Glass, P. Woods, K. Taniguchi, H. F. Clark, B. Forrester, and Fang Z.Y. 1990. Polymerase chain reaction amplification and typing of rotavirus nucleic acid from stool specimens. J. Clin. Microbiol. 28: 276282.

Herring, A. J., N. F. Inglis, C. K. Ojeh, D. R. Snodgrass and Menzies J. D. 1982. Rapid diagnosis of rotavirus infection by direct detection of viral nucleic acid in silver-stained polyacrylamide gels. J. 
Clin. Microbiol. 16: 473-477.

Herring, A. J., N. F. Inglis, C. K. Ojeh, D. R. Snodgrass and Menzies J. D. 1981. Rapid diagnosis of rotavirus infection by direct detection of human and bovine rotavirus in stools: Comparison with electron microscopy, immunoelectroosmophoresis and fluorescent antibody technique. J. Med. Virol. 7: 29-40.

Herring, A. J., N. F. Inglis, C. K. Ojeh, D. R. Snodgrassand Menzies J. D. 1981. Rapid diagnosis of rotavirus infection by direct detection of human and bovine rotavirus in stools: Comparison with electron microscopy, immunoelectroosmophoresis and fluorescent antibody technique. J. Med. Virol.7: 29-40.

Herrmann, J., and Blacklow, N. R. 1995. Gastroenteritis viruses. In: Diagnostic procedures for viral, rickettsial and chlamydial infections (7th Eds.) E. H Lennette, D. A. Lennette and Lennette E. T. Washington DC: American Public Health Association.

Husain, M., P. Seth and Broor S. 1995. Detection of group A rotavirus by reverse transcriptase and polymerase chain reaction in feces from children with acute gastroenteritis. Arch. Virol.,140: 1225-1233.

Junaid, S. A., C. Umeh, A. O. Olabode and Banda J. M. 2011. Incidence of rotavirus infection in children with gastroenteritis attending Jos university teaching hospital, Nigeria. Virol. J. 8: 233.

Kang, G., R. Arora, S. D. Chitambar, J. Deshpande, M. D. Gupte, M. Kulkarni, T. N. Naik, D. Mukherji, S. Venkatasubramaniam, J. R. Gentsch, R. I. Glass and Parashar U. D. 2009. Multicenter, Hospital-Based Surveillance of Rotavirus Disease and Strains among Indian Children Aged 15 Years. J. Infect. Dis. 200: S147.

Kapikian, A. Z., Y. Hoshino and Chanock R.
M. 2001. Rotaviruses. In: Fields virology (4th Eds) D. M. KnipeanfdP. M. Howley. Philadelphia: Lippincott Williams \& Wilkins; pp. 1787-1833.

Kaur, S., 2011. Prevalence and molecular epidemiology of group A rotavirus among children and animal in North India. Ph.D. Thesis, Indian Veterinary Research Institute, Izatnagar, U. P.

Laemmli, U. K., 1970. Cleavage of nonstructural proteins during the assembly of the head of the bacteriophage. Nature. 227: 680-685.

Martella, V., M Ciarlet, K. Banyai, E. Lorusso, A. Cavalli, M. Corrente, G. Elia, S. Aeista, M. Camero, C. Desario, M. Desario, A. Lavazza and Buonavoglia C. 2006. Identification of a novel VP4 genotype carried by a serotype G5 porcine rotavirus strain. Virology. 346: 301-311.

Mathew, M. A., A. Paulose, S. Chitralekha, M. K. Nair, G. Kang and Kilgore P. 2014. Prevalence of rotavirus diarrhoea among hospitalized under-five children. Indian Pediatr. 51(1):27-31.

Million Death Study Collaborators., D. G. Bassani, R. Kumar, S. Awasthi, S. K. Morris and Paul V. K. 2010. Causes of neonatal and child mortality in India: a nationally representative mortality survey. Lancet. 376: 1853-1860.

Parashar, U.D., A. Burton, C. Lanata, C. Boschi-Pinto, K. Shibuya, D. Steele. 2009. Global mortality associated with rotavirus disease among children in 2004. J Infect. Dis. 200: S9-15.

Ramani, S., and Kang, G. 2007. Burden of disease and molecular epidemiology of group A rotavirus infections in India. Indian. J. Med. Res. 125: 619-32.

Samajdar, S., S. Ghosh, M. Chawla-Sarkar, U. Mitrab, P. Dutta, N. Kobayashi and Naik T. N. 2008. Increase in prevalence of human group A rotavirus G9 strains as an important VP7 genotype among 
children in eastern India. J.Clin.Virol. 43:334-39.

Saravanan, P., S. Ananthan and Ananthasubramanian M. 2004. Rotavirus infection among infants and young children in Chennai, South India. Indian. J. Med.Microbiol. 22: 212-21.

Sharma, S., P. Ray, J. R. Gentsch, R. I. Glass, V. Kalra and Bhan M. K. 2008. Emergence of G12 Rotavirus Strains in Delhi, India, in 2000 to 2007. J. Clin.Microbiol. 46:1343-48.

Slovis, N. M., J Elam, M. Estrada and Leutenegger C.M. 2014. Infectious agents associated with diarrhoea in neonatal foals in central Kentucky: a comprehensive molecular study. Equine. Vet. J. 46(3): 311-316.

Steele, A. D., M. C. Niekerk, and Mphahlele M. J. 1995. Geographic distribution of human rotavirus VP4 genotypes and VP7 serotypes in five South African regions. J. Clin. Microbiol. 33: 15161519

Urbina, D., J. G. Rodríguez, O, Arzuza, E. Parra, G. Young, R. Castro and Portillo P. 2004. G and P genotypes of rotavirus circulating among children with diarrhoea in the Colombian northern coast. Int. Microbiol. 7: 113-20.

Ushijima, H., K. Q. Xin, S. Nishimura, S. Morikawa, Abe T. 1994. Detection and sequencing of rotavirus VP7 gene from human materials (stools, sera, cerebrospinal fluids, and throat swabs) by reverse transcription and PCR. J. Clin. Microbiol. 32: 2893-2897.

Vesikari, T., E. Isolauri, E. D. Hondt, A. Delem, F. E. Andre, and Zissis G. 1984. Protection of infants against rotavirus diarrhoea by RIT 4237 attenuated bovine rotavirus strain vaccine. Lancet. 1: 977-981.

WHO, 2009. Manual of rotavirus detection and characterization methods. World Health Organisation, Department of Immunization, Vaccines and Biologicals, Geneva, Switzerland. pp 24-27.

Wilde, J., J. Eiden, and Yolken R. 1990. Removal of inhibitory substances from human faecal specimens for detection of group A rotaviruses by reverse transcriptase and polymerase chain reactions. J. Clin. Microbiol., 28: 13001307.

Xu, L., D. Harbourand McCrae M. A. 1990. The application of polymerase chain reaction to the detection of rotaviruses in faeces. J. Biol. Methods. 27: 29-38.

Yachha, S. K., V. Singh, S. S. Kanwar and Mehta S. 1993. Epidemiology, subgroup and serotypes of Rotavirus diarrhea in north India communities. From the Section of Community Castroenterology and GE Virology, Department of Castroenterology, Postgraduate Institute of Medical Education and Research, Chandigarh 160012.

\section{How to cite this article:}

Gurlal Singh Gill, Simranpreet Kaur, Padam Nath Dwivedi and Jatinder Paul Singh Gill. 2017. Prevalence and Molecular Characterization of Group a Rotavirus in Children of Punjab, India. Int.J.Curr.Microbiol.App.Sci. 6(10): 1231-1242. doi: https://doi.org/10.20546/ijcmas.2017.610.148 